beads, ancient glasses, etc. He was always ready to place his expert microscope technique at the disposal of others, whether to enable them to acquire some small measure of his skill or to help in the elucidation of problems on which critical microscopic observation might be able to throw some light. In his hands, the microscope was an all-revealing instrument, and it was at once a pleasure and an education to be allowed to join with him when there was microscope work to be done.

Very early during the Great War, Sir Herbert Jackson was asked to advise on a variety of urgent chemical problems, and as the extent of his knowledge and the value of the suggestions which he could invariably put forward became more widely known, his advice was increasingly sought. Chief among his many war-time activities must be counted his experimental work on glasses needed for chemical purposes and for X-ray tubes, and, later, his working out of the formulæ for many types of optical glasses not previously manufactured in Great Britain, but essential for such instruments as gun-sighting telescopes, and other optical munitions. In recognition of his valuable war-work, in particular of his work on glass, he was created Knight Commander of the British Empire in 1917, and was elected to the fellowship of the Royal Society in the same year.

When the British Scientific Instrument Research Association was in process of formation under the research association scheme of the Department of Scientific and Industrial Research, Sir Herbert Jackson was invited to become its first director of research. His versatility and his remarkable experimental ability, combined with his keenly analytical mind and quick grasp of essentials, fitted him admirably for this position. Under his guidance, the Association came to be regarded more and more as a source to which any matter concerning the development or manufacture of scientific instruments could be referred with the certainty that useful suggestions would be forthcoming practically at once, if, indeed, a complete solution of the particular problem submitted could not be immediately put forward. Sir Herbert Jackson filled this position with distinction from 1918 until he retired in 1933; he afterwards acted as consultant to the Association, and served as a member of the Association's Research Committee up to the time of his death.

Sir Herbert Jackson held office as president of the Röntgen Society (1901-3) and as president of the Institute of Chemistry (1918-21), and was for some years a member of the senate of the University of London. He served as chairman or as a member of many scientific and advisory Committees, including the Adhesives Committee and the Building Research Advisory Committee of the Department of Scientific and Industrial Research, the Interdepartmental Committee on Optical Glass, the Advisory Committee on Research of the L.M.S. Railway, and others of equal importance.

His death removes one who has rendered valuable service in very many fields, and is deplored by all who were privileged to work with him and to be included in his wide circle of friends.

\section{Captain Oscar Wisting}

Captain Oscar Wistrng, the Norwegian arctic explorer, was born in 1871 and at the age of sixteen years went to sea and in 1892 joined the Norwegian navy. His tastes, however, led him to polar seas, and after a few voyages in whalers and sealers he joined the expedition of R. Amundsen in 1909.

This expedition was originally intended to be an arctic venture but on nows of Peary's attainment of the Pole reaching Europe, Amundsen decided to change his plans and make for the Antarctic. The Fram, Nansen's famous old ship, carried the party to the Ross Sea and their base on the Ice Barrier. Wisting was one of the four men who reached the South Pole on December 14, 1914. Amundsen attributed not a little of their success to Wisting's careful work in making the sledges, clothing and tents for the journey.

Amundsen's next expedition, the exploration of the Arctic Ocean, was delayed by War conditions and the necessity of building a new ship, but when he sailed in 1917 Wisting was his second in command. After three winters in the ice, the Maud, making the North-East passage, reached Alaska, only to return for another winter on the Siberian coast, this time in charge of Wisting, who had only three other men with him. After refitting at Seattle, Wisting again took the Maud north in 1922 and returned five years later, having failed to penetrate the inner arctic seas.

In 1926 Wisting was one of the men who accompanied Amundsen in the airship Norge in its flight of 3,393 miles from Spitsbergen across the Pole to Teller, in Alaska. When Nobile's airship Italia came to grief in 1928, Amundsen flew to the rescue from Norway. On the disappearance of his aeroplane Wisting went to Spitsbergen to join the vain search.

In 1926 Wisting retired from the navy with the rank of captain and in recent years had been custodian of the Fram, which is now kept on land at Oslo as a polar museum. It was on board the Fram that he died on December 4.

R. N. R. B.

\section{Señor Don Juan de la Cierva}

The death of Señor Cierva in the accident to a Dutch air liner on December 9 is a grave loss to aeronautical science. Fourteen years ago he invented the main principles of the autogiro, and in the intervening years he was assiduous in working, chiefly in England, on schemes for its improvement. His very latest model, the direct lift type, after being successfully demonstrated, has now reached the point of being built in numbers. Hence its inventor may be said to have lived just long enough to see his invention reach the fullest development attainable by that type of aircraft.

Señor Cierva was born in 1895 at Murcia in Spain. $\mathrm{He}$ received his scientific training at the Civil Engineering School in Madrid, and four years later he began his work on rotating wing aircraft, being convinced from his experienee of the fixed wing type that the danger of accident by stalling was irremovable by other means. In his new plans he 
arranged for the peripheral speed of his 'windmill' to be several times as great as the highest horizontal speed of the entire craft, and since this peripheral speed remained nearly constant, the craft could always count on adequate lift, however slowly the machine as a whole might be flying. In fact experiment soon showed that against a modest wind of twenty miles an hour or so, the autogiro could keep station in descent over a definite spot on the ground.

The autogiro could, however, not compete with a helicopter in vertical 'take-off', and it was to this point that Señor Cierva devoted the later years of his life. He devised a mechanism whereby the pitch angle of the rotating blades of the windmill could be changed, and he used this mechanism to change, from a zero pitch angle to a large one, the angle of attack of the rotating blades at the moment of starting flight. This caused the craft literally to jump into the air -as much as 30 feet-and then to climb on a gentle path free from ground obstructions. In this way, the inventor considered that he had added to his autogiro the main advantage claimed for the helicopter of being able to rise from a very small field.

At each stage in the development of his ideas, Señor Cierva gave an account of his work to the Royal Aeronautical Society, of which he was a fellow. From that Society he received its Silver
Medal and later the Wakefield and Guggenheim Gold Medals. In his lifetime he always expressed himself warmly on the recognition he received from the Royal Aeronautical Society, as he did on the encouragement given to him by the Air Ministry and the Aeronautical Research Committee, from his earliest flying demonstration to an astonished assemblage at Farnborough until the day of his death.

We regret to announce the following deaths:

Dr. L. Gustave Binger, correspondant for the Section of Geography and Navigation of the Paris Academy of Sciences.

Prof. William Campbell, Howe professor of metallurgy in Columbia University, an authority on physical metallurgy, on December 16, aged sixty years.

Prof. Augustus H. Gill, emeritus professor of chemistry in the Massachusetts Institute of Technology, an authority on hydrocarbons, on November 11, aged seventy-two years.

Prof. Edouard J. B. Goursat, formerly professor of mathematics in the Sorbonne, on November 26, aged seventy-eight years.

Dr. Henry B. Hedrick, formerly ballistician in the U.S. Ordnance Department, known for his work on the preparation of mathematical tables, on October 6, aged seventy-one years.

\section{News and Views}

\section{Louis-Bernard Guyton de Morveau (I737-1816)}

Ter bicentenary of the birth of Guyton de Morveau recalls the career of a man of science who was a prominent figure in what is, perhaps, the most interesting epoch in the history of science in France, if not in French history itself. Ingenious, versatile and courageous, he engaged in many enterprises and as a man of science had a wide reputation. Born at Dijon on January 4, 1737, Guyton de Morveau was the son of the professor of civil law in that city. $\mathrm{He}$ himself was educated for the law at Dijon and Paris, and after he had practised for a short time, his father procured for him at the price of 40,000 francs the appointment of advocate general to the local parliament at Dijon, which he held for twenty-three years. Always of an inquiring mind, he becarme attached to the Academy of Sciences in his native city, devoted himself to the study of chemistry--being assisted by Baumé-and in 1776 began to lecture on that subject. He also established on scientific principles a saltpetre factory which was conducted by Courtois, the father of the discoverer of iodine. He became acquainted with the men of science in Paris, and in 1780 he was induced by Panckoucke, the bookseller, to undertake the chemical section of the famous "Encyclopédie Methodique". Seven years later he joined Lavoisier, Berthollet and Fourcroy in the publication of the "Methode de Nomenclature Chimique", which revolutionized chemical nomenclature.

As with so many of his countrymen, at the outbreak of the Revolution, de Morveau's energies were diverted into another channel. He was chosen a deputy to the Legislative Assembly, of which he became secretary in 1791, and president the following year. In the Convention he was one of those who voted for the King's death; and in 1794 he accompanied the army into Belgium and made balloon ascents at the battle of Fleurus. With the return of more settled conditions he was made a professor in the newly founded Ecole Polytechnique, and in 1795 was chosen a member of the Council of Five Hundred, and also one of the forty-eight members of the National Institute which had arisen over the ashes of the old aeademies. He acted as director of the Ecole Polytechnique during the absence of Monge, who had accompanied Napoleon to Egypt, and he continued to lecture there until he was seventy-six years of age. He was made a baron in 1811, and died in Paris on January 2, 1816. The range of his writings can be seen from the list of more than 190 papers appended to the biographical sketch of him by Thomas Young in the earlier editions of the 